\title{
Effectiveness of different auxiliary chemical substances in the rapid disinfection of gutta-percha points - an in vitro study
}

\author{
Eficácia de diferentes substâncias químicas auxiliares na rápida \\ desinfecção de cones de guta-percha - estudo in vitro
}

Maico Henrique Manica Schmidt ${ }^{*}$ Rafaela Flores Sallenave*

Aline Demarchi**

Ana Paula Farina**

Doglas Cecchin ${ }^{* * *}$

Matheus Albino Souza ${ }^{* * *}$

\section{Abstract}

Objective: to perform an in vitro assessment of the effectiveness of different auxiliary chemical substances used to promote decontamination of gutta-percha points contaminated with different microorganisms. Materials and method: the microorganisms tested were strains of Enterococcus faecalis, Candida albicans, and Staphylococcus aureus. The 72 gutta-percha points were divided into three groups of 24 points and individually transferred into three tubes containing $5 \mathrm{ml}$ of each bacterial suspension for 1 hour. The 24 gutta-percha points of each bacterial strain were randomly distributed into six groups $(n=4)$ based on auxiliary chemical substance and period of decontamination, as follow: G1 (distilled water; DW); G2 (2.5\% sodium hypochlorite; NaOCl); G3 $\left(2.5 \%\right.$ calcium hypochlorite; $\left.\mathrm{Ca}(\mathrm{OCl})_{2}\right) ; \mathrm{G} 4(2 \%$ chlorhexidine gel; CHX); G5 (QMix); and G6 (6.5\% grape seed extract; GSE). There were four evaluation periods (30, 60, 90, and 120 seconds). After disinfecting, the gutta-percha points were transferred to tubes containing $450 \mu \mathrm{L}$ of sterile saline solution, homogenized, and diluted. Aliquots of $100 \mu \mathrm{L}$ of the solution and the dilutions were cultivated in duplicate on plates containing blood agar. This material was incubated for 48 hours at $37^{\circ} \mathrm{C}$. Next, the number of colony-forming units $(\mathrm{CFU} / \mathrm{mL})$ was counted. Results: groups G2 (Na$\mathrm{OCl}), \mathrm{G} 3\left(\mathrm{Ca}(\mathrm{OCl})_{2}\right), \mathrm{G} 4(\mathrm{CHX})$, and G5 (QMix) sho- wed no bacterial growth of tested microorganisms at all periods of observation, and were statistically different from all other groups ( $p<0.05)$. Group G6 (GSE) showed better antimicrobial activity $(p<0.05)$ against Enterococcus faecalis, Candida albicansi, and Staphylococcus aureus when compared to G1 (DW). Conclusion: we determined that $2.5 \%$ sodium hypochlorite, $2.5 \%$ calcium hypochlorite, $2 \%$ chlorhexidine gel, and QMix might be used as effective agents for rapidly disinfecting contaminated gutta-percha points after 30 seconds of use.

Keywords: Calcium hypochlorite. QMix. Grape seed extract. Enterococcus faecalis. Candida albicans. Staphylococcus aureus.

\section{Introduction}

Microorganisms and their products are the main etiological factor of pulpal and periapical pathologies, and they playing a significant role in the induction and progression of these conditions ${ }^{1,2}$. Hence, chemomechanical preparation, through the mechanical action of endodontic instruments and the chemical action of endodontic irrigants, is per-

DDS, University of Passo Fundo, Passo Fundo, RS, Brazil.
Graduate student, University of Passo Fundo RS, Brazil.

* PhD, University of Passo Fundo RS, Brazil. 
formed to eliminate microorganisms from the root canal system without injuring the adjacent vital tissues ${ }^{3}$.

The maintenance of an aseptic chain is the key to a successful root canal therapy. Care should be taken in all stages of the endodontic treatment, from coronal surgery to root canal filling. Gutta-percha (GP) is a dried coagulated extract of plants of palaquium of the Blanco genus of Sapotaceae family ${ }^{4}$. Due to its biological and physical properties, it is still an important dental material, emerging as the prime root canal filling material ${ }^{5}$. However, gutta-percha points are usually used directly from the package without regard to their sterility, and may showing contamination ${ }^{6}$. However, standard autoclave and high temperature sterilization methods deform this kind of material. As a result, rapid decontamination using auxiliary chemical substances is necessary to promote the sterilization of gutta-percha points and prevent microorganisms from entering the root canal system, which underwent chemomechanical preparation during the root canal filling process.

Sodium hypochlorite and chlorhexidine have been used as irrigants in the root canal therapy due to their broad-spectrum antimicrobial activi$t^{7,8}$. At the same time, auxiliary chemical substances, such as calcium hypochlorite, QMix, and grape seed extract, have also been tested in endodontics and have shown antimicrobial activity ${ }^{9-11}$. However, there is no consensus in the literature on which of these chemical methods best decontaminates gutta-percha points.

The aim of this study was to perform an in vitro assessment of the effectiveness of different auxiliary chemical substances used to disinfect gutta-percha points contaminated with different microorganisms.

\section{Materials and method}

Enterococcus faecalis (ATCC 28713), Candida albicans (ATCC 22179), and Staphylococcus aureus (ATCC 29415) strains were obtained from the Department of Microbiology of the Biological Science Institute of the University of Passo Fundo. Pure microorganism culture strains were cultivated in test tubes containing $5 \mathrm{ml}$ of the Brain-Heart Infusion (BHI) broth and incubated for $24 \mathrm{~h}$ at $37{ }^{\circ} \mathrm{C}$. After bacterial growth, the concentration was agitated and regulated to the $0.5 \mathrm{McF}$ arland scale $\left(1.5 \times 10^{8}\right.$ $\mathrm{CFU} / \mathrm{ml}$ ). This study used 72 \#40 main gutta-percha points (Tanari $^{\circledast}$ - Tanariman Industrial Ltda., Manacapuru, AM, Brazil), which were divided into three groups of 24 points and individually transferred into three tubes containing $5 \mathrm{ml}$ of each bacterial suspension $\left(1.5 \times 10^{8} \mathrm{CFU} / \mathrm{ml}\right)$ for 1 hour.

The 24 gutta-percha points of each bacterial strain were randomly distributed into six groups $(n=4)$ according to chemical auxiliary substances and period of decontamination, as follow: G1 (distilled water; DW; Natupharma, Passo Fundo, RS, Brazil); G2 (2.5\% sodium hypochlorite; NaOCl; Lírios, São Vicente, SP, Brazil); G3 (2.5\% calcium hypochlorite; $\mathrm{Ca}(\mathrm{OCl})_{2}$; R\&D Laboratories Ltd, Antrim, Northern Ireland, UK); G4 (2\% chlorhexidine gel; CHX; Natupharma, Passo Fundo, RS, Brazil); G5 (QMix; Dentsply, York, PA, United States); and G6 (6.5\% Grape Seed Extract; GSE; ver Healthy Origins, Pittsburgh, PA, United States of America). The four gutta-percha points of each decontamination protocol were subdivided in four assessment periods (30, 60, 90, and 120 seconds). Table 1 helps to illustrate the groups' distribution.

After disinfection, all of the gutta-percha points were individually transferred to tubes containing $450 \mu \mathrm{L}$ of sterile saline solution at a concentration of $0.85 \%$. The material was homogenized and diluted to $10^{-3}$. Aliquots of $100 \mu \mathrm{L}$ of the solution and the dilutions were cultivated in duplicate on the surface of plates containing blood for 48 hours at $37{ }^{\circ} \mathrm{C}$. After the incubation period, the number of colony-forming units $(\mathrm{CFU} / \mathrm{mL})$ on each plate was determined.

The one-way ANOVA test was used for the microbiologic evaluation, followed by Tukey's post hoc procedure, at 5\% of significance level. Data were analyzed using SPSS version 17.0 (SPSS, Chicago, IL, United States).

\section{Results}

Table 1 and Figure 1 illustrate the results of the present study.

Table 1 - Comparison of the antimicrobial activity of decontamination protocols expressed in log CFU/mL

\begin{tabular}{|c|c|c|c|c|}
\hline Group & $\begin{array}{l}\text { Enterococcus } \\
\text { faecalis }\end{array}$ & $\begin{array}{l}\text { Candida } \\
\text { albicans }\end{array}$ & $\begin{array}{c}\text { Staphylococcus } \\
\text { aureus }\end{array}$ & $p$ value \\
\hline 1. DWa & $3.78 \pm 0.16$ & $3.43 \pm 0.21$ & $3.57 \pm 0.14$ & $\mathrm{p}<0.05$ \\
\hline 2. $\mathrm{NaOCl}^{\mathrm{b}}$ & $0.00 \pm 0.00$ & $0.00 \pm 0.00$ & $0.00 \pm 0.00$ & $\mathrm{p}<0.05$ \\
\hline 3. $\mathrm{Ca}(\mathrm{OCl})_{2}^{\mathrm{b}}$ & $0.00 \pm 0.00$ & $0.00 \pm 0.00$ & $0.00 \pm 0.00$ & $\mathrm{p}<0.05$ \\
\hline 4. $\mathrm{CHX}^{\mathrm{b}}$ & $0.00 \pm 0.00$ & $0.00 \pm 0.00$ & $0.00 \pm 0.00$ & $p<0.05$ \\
\hline 5. QMix & $0.00 \pm 0.00$ & $0.00 \pm 0.00$ & $0.00 \pm 0.00$ & $\mathrm{p}<0.05$ \\
\hline 6. GSE ${ }^{\mathrm{c}}$ & $3.36 \pm 0.12$ & $2.80 \pm 0.14$ & $3.13 \pm 0.10$ & $\mathrm{p}<0.05$ \\
\hline
\end{tabular}

${ }^{*}$ Data are presented as mean \pm standard deviation of colony-forming units (log CFU/mL). P values are significant using the analysis of variance on ranks. Different index letters represent statistical significant difference at the post hoc procedure (Tukey's test). ${ }^{\star *} \mathrm{DW}=$ distilled water; $\mathrm{NaOCl}=2.5 \%$ sodium hypochlorite; $\mathrm{Ca}(\mathrm{OCl})_{2}=2.5 \%$ calcium hypochlorite; $\mathrm{CHX}=2 \%$ chlorhexidine gel; QMix= QMix; GSE= 6.5\% grape seed extract. 


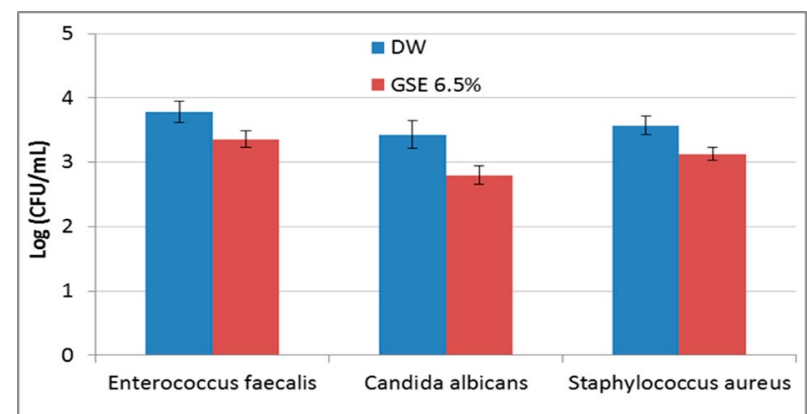

Figure 1 - Microbiological analysis: chart representing the mean and standard deviation of the colony-forming units (log CFU/ $\mathrm{mL}$ ) of the tested microorganisms from G1 (DW) and G6 (GSE). DW= distilled water; GSE $=6.5 \%$ grape seed extract. The groups G2 ( $\mathrm{NaOCl}), \mathrm{G} 3\left(\mathrm{Ca}(\mathrm{OCl})_{2}\right), \mathrm{G} 4(\mathrm{CHX})$, and G5 (QMix) are not shown in the figure, since the counting of CFUs was zero for all tested microorganisms during all periods of observation

After microbiological analysis and determination of the number of CFU, groups $\mathrm{G} 2(\mathrm{NaOCl}), \mathrm{G} 3$ $\left(\mathrm{Ca}(\mathrm{OCl})_{2}\right)$, G4 (CHX), and G5 (QMix) did not show growth of the tested microorganisms for any of the periods of observation, with the results being statistically different from all other groups $(p<0.05)$. Group G1 (DW) and G6 (GSE) showed growth of the tested microorganisms for all of the observation periods, with no statistically significant difference between the observation periods for both groups $(\mathrm{p}<0.05)$. In other words, treatment time did not influence the decontamination process for these substances. However, G6 (GSE) showed better $(\mathrm{p}<0.05)$ antimicrobial activity against Enterococcus faecalis, Candida albicans, and Staphylococcus aureus when compared to G1 (DW). At the same time, G6 (GSE) showed antimicrobial activity against the tested microorganisms in the following ascending order: Candida albicans (2.80 log CFU/ $\mathrm{mL}$ ), Staphylococcus aureus (3.13 $\log \mathrm{CFU} / \mathrm{mL}$ ), and Enterococcus faecalis (3.36 $\log \mathrm{CFU} / \mathrm{mL}$ ), with a statistically significant difference between the tested microorganisms $(\mathrm{p}<0.05)$.

\section{Discussion}

The neutralization of microorganisms from the root canal system is essential for long-term success of endodontic therapy. Furthermore, the filling materials prevent infection by acting as a barrier to further microbial challenges, trapping any surviving bacteria within the root canal system and stopping periapical tissue fluids from reaching bacteria in the root canal ${ }^{12}$. The importance of decontamination of gutta-percha points prior to root canal filling is widely recognized to prevent any microbial contamination of the root canal system during filling. Thus, it is imperative to use a rapid, reliable, inexpensive, and effective decontaminating substance.

The decontamination protocols used in the present study were tested against three strains of microorganisms. Although the environment may have more than three species of microorganisms, Enterococcus faecalis, Candida albicans, and Staphylococcus aureus were chosen because they represent microorganism species that are resistant and frequently found in the microbiota of infected root canals $\mathbf{s}^{13-15}$. Therefore, rapid sterilization by the tested protocols may be tested in an adequate way considering these microorganisms represent a risk factor to be inserted into the root canal system if decontamination procedures of gutta-percha points are not performed, increasing the possibility of failure of root canal therapy. Therefore, if a chemical agent is able to kill these pathogens, it may destroy any other microorganism at the same temperature and time.

Previous studies have used various methods, such as an agar diffusion test ${ }^{16}$ and turbidity as an indicator of microbial growth ${ }^{17,18}$ for quantifying microorganisms. On the other hand, counting the number of CFUs (expressed as log CFU/ml) is one of the most frequently used methods to assess the antimicrobial activity of endodontic decontamination protocols ${ }^{19-21}$. For this reason, we chose this method for the present study, thus allowing bacterial quantification ${ }^{22}$ and assessment of the effectiveness of the tested protocols for the decontamination of gutta-percha points.

According to results of the present study, G2 $(\mathrm{NaOCl})$ and $\mathrm{G} 4$ (CHX) promote complete elimination of Enterococcus faecalis, Candida albicansi, and Staphylococcus aureus, even after just 30 seconds. This is due to the broad-spectrum antimicrobial activity of sodium hypochlorite ${ }^{7,23}$ and chlorhexidine $^{8,24}$. Our findings are in agreement with previous studies ${ }^{17,18}$ where the same chemical auxiliary substances were effective in promoting the rapid sterilization of gutta-percha points. However, gutta-percha points that are immersed in sodium hypochlorite solution formed chloride-crystal on its surface. These sodium hypochlorite crystals on the gutta-percha points impair the ability of the filling material to promote an adequate sealing ${ }^{6}$, which is a disadvantage of this kind of method for the rapid sterilization of gutta-percha points. Similarly, G3 $\left(\mathrm{Ca}(\mathrm{OCl})_{2}\right)$ and $\mathrm{G} 4$ (QMix) showed similar results to the $2.5 \%$ sodium hypochlorite and $2 \%$ chlorhexidine gel. Calcium hypochlorite $\left(\mathrm{Ca}(\mathrm{OCl})_{2}\right)$ is normally used for industrial sterilization and water purification treatments. $\mathrm{Ca}(\mathrm{OCl})_{2}$ is available in granules and the formation of hypochlorous acid $(2(\mathrm{HOCl}))$ occurs when they are dissolved in an aqueous solution ${ }^{25}$. The high level of available chlorine in $\mathrm{Ca}(\mathrm{OCl})_{2}$ may help to explain its antimicrobial activity. On the other hand, QMix is an endodontic irrigant with no chair-side mixing used for smear layer removal with added antimicrobial agents. Further EDTA and a detergent containing chlorhexidine. Its effectiveness against a large number of microorganisms is due to the interactions between 
the positive charges of the chlorhexidine with the negatively charged bacterial cell wall, thus altering the osmotic balance of the cell. This causes an increase in the permeability of the cell wall, which allows for the penetration of chlorhexidine molecules into the bacteria and, consequently, causes the death of these microorganisms ${ }^{26}$.

In the present study, G6 (GSE) was not able to eliminate all of the tested microorganisms at all observation periods, even after 2 minutes of action. However, the decontamination potential of $6.5 \%$ GSE was higher than DW. GSE is a rich source of proanthocyanidins (PAs) ${ }^{27}$. PAs have gained attention due to their antimicrobial and anti-inflammatory properties ${ }^{28}$, as well as their use in prevention of periodontal diseases ${ }^{29,30}$. The antimicrobial activity of PAs helps to explain some of the ability of 6.5\% GSE to reduce the microbial content of gutta-percha points. However, according to the present results, 6.5\% GSE cannot be used as a chemical agent for the rapid sterilization of gutta-percha points since it was not able to eliminate the tested microorganisms.

\section{Conclusion}

Based on results of the present study, Enterococcus faecalis was the most resistant microbial specie against the antimicrobial activity of $6.5 \%$ GSE. Enterococcus faecalis is an anaerobic facultative microorganism that is highly resistant to conventional chemomechanical preparation and is usually found in cases of failed root canal treatment ${ }^{31}$. This microorganism has several virulence factors and is able to withstand prolonged periods of nutrient limitation, thus persisting as a pathogen in the root canal $^{32,33}$. It is possible that $6.5 \%$ GSE did not show potential antimicrobial activity against this microorganism for these reasons, thus resulting in a high mean $\mathrm{CFU}$ (3.36 $\log \mathrm{CFU} / \mathrm{mL})$.

Based on our results, we believe that $2.5 \%$ sodium hypochlorite, $2.5 \%$ calcium hypochlorite, $2 \%$ chlorhexidine gel, and QMix may be used as effective agents for the rapid sanitization of contaminated gutta-percha points after 30 seconds of use. However, $6.5 \%$ GSE cannot be used as a decontamination agent since it did not promote the elimination of the tested microorganisms from the surface of the gutta-percha points. In addition, further studies should be performed to assess the effect of these auxiliary chemical substances on changes in the physical properties of the filling material for clinical relevance.

\section{Acknowledgements}

** The authors deny any conflicts of interest.

** We have no financial affiliation (e.g. employment, direct payment, stock holdings, retainers, consultantships, patent licensing arrangements, or honoraria) or involvement with any commercial organisation with direct financial interest in the subject or materials discussed in this manuscript, nor have any such arrangements existed in the past three years.

\section{Resumo}

Objetivo: avaliar in vitro a eficácia de diferentes substâncias químicas auxiliares utilizadas para promover a descontaminação de cones de guta-percha, que estão contaminados com diferentes microorganismos. Materiais e método: cepas Enterococcus faecalis, Candida albicans e Staphylococcus aureus foram os microrganismos testados. Os 72 cones de guta-percha foram divididos em três grupos de 24 cones, e foram transferidas individualmente em três tubos, contendo $5 \mathrm{ml}$ de cada suspensão bacteriana, durante 1 hora. Os 24 cones de guta-percha de cada estirpe bacteriana foram distribuídos aleatoriamente em seis grupos $(n=4)$, de acordo com a substância química auxiliar e com o tempo de descontaminação, como segue: G1 (DW) - água destilada; G2 (NaOCl) - hipoclorito de sódio a 2,5\%; G3 (Ca (OCl) 2) - 2,5\% de hipoclorito de cálcio; G4 (CHX) - clorexidina gel 2\%; G5 (QMix) - QMix e G6 (GSE) - Extrato de Semente de Uva 6,5\%, em quatro períodos de avaliação, que foram 30, 60, 90 e 120 segundos. Depois de protocolos de desinfecção das pontas de guta-percha, foram transferidos para tubos contendo $450 \mathrm{~mL}$ de solução salina estéril, homogeneizada e diluída. Alíquotas de $100 \mu \mathrm{l}$ da solução e as diluições foram cultivadas em duplicado em placas de ágar contendo o sangue. Esse material foi incubado durante 48 horas a $37^{\circ} \mathrm{C}$ de temperatura. Depois disso, a contagem do número de unidades formadoras de colônias (CFU $/ \mathrm{mL}$ ) foi realizada. Resultados: os grupos 2 ( $\mathrm{NaOCl}$, 3 (Ca $(\mathrm{OCl}) 2), 4(\mathrm{CHX})$ e 5 (QMix) não apresentaram crescimento bacteriano de microrganismos testados em todos os períodos de observação, sendo estatisticamente diferente de todos os outros grupos $(p<0,05)$. O Grupo 6 (GSE) mostrou a melhor atividade antimicrobiana contra albicans Enterococcus faecalis e Candida Staphylococcus aureus em relação ao grupo 1 (DW), sendo estatisticamente diferente $(p<0,05)$. Conclusão: hipoclorito de sódio a 2,5\%, 2,5\% de hipoclorito de cálcio, 2\% de gel de clorexidina e QMix podem ser utilizados como agentes eficazes na desinfecção rápida de cones de guta-percha contaminados após 30 segundos de utilização dessas substâncias.

Palavras-chave: Hipoclorito de cálcio. QMix. Extrato de semente de uva. Enterococcus faecalis. Candida albicans. Staphylococcus aureus.

\section{References}

1. Sundqvist G. Bacteriological studies of necrotic dental pulps [Thesis]. Umea (Sweden): University of Umea; 1976.

2. Kakehashi S, Stanley HR, Fitzgerald RJ. The effects of surgical exposures of dental pulps in germ-free and conventional laboratory rats. Oral Surg Oral Med Oral Pathol 1965;20:340-9. 
3. Seltzer S, Bender IB. Factors affecting successful repair after root canal therapy. J Am Dent Assoc 1963;67:651-62.

4. Jyoti BB. Phytotherapeutics in conservative dentistry and endodontics - a review. J Conserv Dent. 2005;8:31-9.

5. Gurgel-Filho ED, Andrade Feitosa JP, Teixeira FB, Monteiro de Paula RC, Araújo Silva JB, Souza-Filho FJ. Chemical and $\mathrm{X}$-ray analyses of five brands of dental gutta-percha cone. Int Endod J 2003;36:302-7.

6. Short RD, Dorn SO, Kuttler S. The crystallization of sodium hypochlorite on gutta-percha cones after the rapid-sterilization technique: an SEM study. J Endod 2003;29:670-3.

7. Du T, Wang Z, Shen Y, Ma J, Cao Y, Haapasalo M. Effect of long-term exposure to endodontic disinfecting solutions on young and old Enterococcus faecalis biofilms in dentin canals. J Endod 2014;40:509-14.

8. Ferraz CC, Gomes BP, Zaia AA, Teixeira FB, Souza-Filho FJ. In vitro assessment of the antimicrobial action and the mechanical ability of chlorhexidine gel as an endodontic irrigant. J Endod 2001;27:452-5.

9. Buchholz A, Matthews KR. Reduction of Salmonella on alfalfa seeds using peroxyacetic acid and a commercial seed washer is an effective as treatment with $20.000 \mathrm{ppm}$ of $\mathrm{Ca}$ (OCl)2. Lett Appl Microbiol 2010;51:462-8.

10. Stojicic S, Shen Y, Qian W, Johnson B, Haapasalo M. Antibacterial and smear layer removal ability of a novel irrigant, QMix. Int Endod J 2012;45:363-71.

11. Kolodziej H, Haberland C, Woerdenbag HJ, Konings AWT. Moderate cytotoxicity of proanthocyanidins to human tumour cell lines. Phytother Res 1995;9:410-5.

12. Sundqvist G, Figdor D. Endodontic treatment of apical periodontitis. In: Orstavik D, Pitt Ford T. Essential endodontology. Oxford: Blackwell Publishing; 2003. p. 242-77.

13. Fouad AF, Zerella J, Barry J, Spångberg LS. Molecular detection of Enterococcus species in root canals of therapy-resistant endodontic infections. Oral Surg Oral Med Oral Pathol Oral Radiol Endod 2005;99:112-8.

14. Baumgartner JC, Watts CM, Xia T. Occurrence of Candida albicans in infections of endodontic origin. J Endod 2000;26:695-8.

15. Mattigatti S, Ratnakar P, Moturi S, Varma S, Rairam S. Antimicrobial effect of conventional root canal medicaments vs propolis against Enterococcus faecalis, Staphylococcus aureus and Candida albicans. J Contemp Dent Pract 2012;13:305-9.

16. Bodrumlu E, Alaçam T. Evaluation of antimicrobial and antifungal effects of iodoform-integrating gutta-percha. J Can Dent Assoc 2006;72:733a-d.

17. Subha N, Prabhakar V, Koshy M, Abinaya K, Prabu M, Thangavelu L. Efficacy of peracetic acid in rapid disinfection of Resilon and gutta-percha cones compared with sodium hypochlorite, chlorhexidine, and povidone-iodine. J Endod 2013;39:1261-4.

18. Ozalp N, Okte Z, Ozcelik B. The rapid sterilization of gutta-percha cones with sodium hypochlorite and glutaraldehyde. J Endod 2006;32:1202-4.

19. Evans MD, Baumgartner JC, Khemaleelakul S, Xia T. Efficacy of calcium hydroxide: chlorhexidine paste as an intracanal medication in bovine dentine. J Endod 2003;29:338-9.

20. Menezes MM, Valera MC, Jorge AOC, Koga-Ito CY, Camargo CHR, Mancini MNG. In vitro evaluation of the effectiveness of irrigants and intracanal medicaments on microorganisms within root canals. Int Endod J 2004;37:311-9.
21. Grundling GL, Zechin JG, Jarduim WM, Oliveira SD de, Figueiredo JA de. Effect of ultrasonics on Enterococcus faecalis biofilm in a bovine tooth model. J Endod 2011;37:1128-33.

22. Peters LB, Wesselink PR, Moorer WR. The fate and the role of bacteria left in root dentinal tubules. Int Endod J 1995;28:95-9.

23. Niazi SA, Clark D, Do T, Gilbert SC, Foschi F, Mannocci F, et al. The effectiveness of enzymic irrigation in removing a nutrient-stressed endodontic multispecies biofilm. Int Endod J 2014;47:756-68.

24. Dametto FR, Ferraz CC, Gomes BPFA, Zaia AA, Teixeira FB, Souza-Filho FJ. In vitro assessment of the immediate and prolonged antimicrobial action of chlorhexidine gel as an endodontic irrigant against Enterococcus faecalis. Oral Surg Oral Med Oral Pathol Oral Radiol Endod. 2005;99(6):768-72.

25. Dutta A, Saunders WP. Comparative evaluation of calcium hypochlorite and sodium hypochlorite on soft-tissue dissolution. J Endod 2012;38:1395-8.

26. Gomes BPFA, Souza SFC, Ferraz CCR, Teixeira FB, Zaia AA, Valdrighi L, et al. Effectiveness of $2 \%$ chlorhexidine gel and calcium hydroxide against Enterococcus faecalis in bovine root dentine in vitro. Int Endod J 2003;36:267-75.

27. Wu CD. Grape products and oral health. J Nutr 2009;139:1818-23.

28. Kolodziej H, Haberland C, Woerdenbag HJ, Konings AWT. Moderate cytotoxicity of proanthocyanidins to human tumour cell lines. Phytother Res 1995;9:410-5.

29. Houde V, Grenier D, Chandad F. Protective effects of grape seed proanthocyanidins against oxidative stress induced by lipopolysaccharides of periodontopathogens. J Periodontol 2006;77:1371-9.

30. La VD, Bergeron C, Gafner S, Grenier D. Grape seed extract suppresses lipopolysaccharide-induced matrix metalloproteinase (MMP) secretion by macrophages and inhibits human MMP-1 and -9 activities. J Periodontol 2009;80:187582.

31. Pinheiro ET, Gomes BPFA, Ferraz CCR, Sousa ELR, Teixeira FB, Souza Filho FJ. Microorganisms from canals of root-filled teeth with periapical lesions. Int Endod J 2003;36:1-11.

32. Tendolkar PM, Baghdayan AS, Shankar N. Pathogenic enterococci: new developments in the 21st century. Cell Mol Life Sci 2003;60:2622-36.

33. Figdor D, Davies JK, Sundqvist G. Starvation survival, growth and recovery of Enterococcus faecalis in human serum. Oral Microbiol Immunol 2003;18(4):234-9.

\section{Endereço para correspondência:}

Matheus Albino Souza

Post-Graduate Program in Dentistry

University of Passo Fundo

BR 285/São José, Building A7, suite 2. Zip

99052-900 Passo Fundo - RS - Brazil

Phone: +55 54 3316-8402

E-mail: matheus292@yahoo.com.br matheussouza@upf.br

Recebido: 01/02/2015. Aceito: 08/04/2015. 